\title{
The Role of Forensic Audit on Management Frauds in Nigerian Deposit Money Banks
}

\section{Olofinlade Samuel Oluwapelumi}

Department of Finance, Faculty of Management Science, Ekiti State University, Ado-Ekiti, Nigeria

\section{Email address:}

olofin73@gmail.com

\section{To cite this article:}

Olofinlade Samuel Oluwapelumi. The Role of Forensic Audit on Management Frauds in Nigerian Deposit Money Banks. International Journal of Accounting, Finance and Risk Management. Vol. 6, No. 3, 2021, pp. 69-75. doi: 10.11648/j.ijafrm.20210603.11

Received: June 22, 2021; Accepted: July 8, 2021; Published: July 29, 2021

\begin{abstract}
This study investigates the role of forensic audit on management frauds in Nigerian deposit money banks'. Specifically, the paper examines the nexus that exists between forensic audit/accounting mechanisms on prevention of management frauds in Nigeria deposit money banks. The data for this paper were obtained from secondary source which were gathered from the audited financial statements as well as accounts of some of the listed deposit money banks in Nigeria. The study is descriptive and highly empirical as it involves the use of panel regression technique as tool of analysis. The result findings from regression analysis reveal from hypothesis one that there exist a meaningful and positive nexus between forensic audit and prevention and curbing of management fraud in Nigeria deposit money banks, also findings outcome from hypothesis two reveal that there is a strong and positive nexus between forensic audit mechanism and faithful representation of financial statements while the third hypothesis establish a strong correlation between financial accounting and understandability of financial statements. This affirms that forensic accounting/audit mechanisms are related tools towards preventing management frauds, faithful representation of financial records and understandability of financial statements. The study therefore recommends that the financial regulators as well as deposit money banks in Nigeria should undergo training and re-training of their strategic level management and staff on the intricacies of forensic accounting/audit so as to maximize shareholders wealth and be fair to other stakeholders.
\end{abstract}

Keywords: Forensic Audit/Accounting, Management Fraud, Positive Accounting Theory

\section{Introduction}

Many dreams of successful shareholders and promoters would have been unsuccessful and non-achievable if not for involvement of different managers in different fields. Management consists of different professionals from diverse fields who are engaged to carry on the activities of the organization in order to achieve organisational objectives. They make use of various methods and set divergent policies so as to safeguard company's resources and achieve set goals.

In the height of these, they engage in management earnings which may be known as management fraud or financial statements frauds.

To this end, scholars of repute and researchers were of the view that this instrument has been used by management for and against organizations/firms. However, management fraud is mainly carried out by top level management which is persuaded with robust benefits so as to achieve perfect expectations of the capital market. This is done in order to keep firm's stock price at dividend attractive and sound position for return on investment for willing and current investors or entrepreneur. Hence some top management do involve in income smoothing so as to hide the truth from the auditors and other stakeholders.

Besides, some authors and researchers have divergent views on management frauds as it persists due to the lackadaisical or willingness of top management in the financial forensic process. Ezeagba [8] is of the opinion that most of unfortunate incidences in the deposit money banks could be traced to poor corporate governance which directly or negatively affected the quality assurance in financial reporting. Sequel to this, the Central Bank of Nigeria (2019) affirmed that most chief executives of the commercial banking sector had involve in one management frauds as a result of many misleading financial reports releases and published for numerous stakeholders consumption as the true 
and fair representation of their financial records and the sent to the Central bank of Nigeria as their financial record.

On this background, there is a need for the banking sector to look for qualified professional which can look beyond figures and financial statements prepared and presented by directors as required by the Act for audit exercise. Hence the need for the usefulness of the forensic accounting to entrenches quality assurance of financial statements, to unveil hidden financial reports frauds, and looks beyond mire compliances to management guidelines and procedures. Centre for Forensic Studies [4] calls for the engagement of forensic accounting for turning the leakages in banking sector to stepping stone in preventing corporate fraud as cited from Institute of Chartered Accountants England and Wales [16].

In the light of the above arguments, among the scholars who have contributed to existing trend in the field of forensic accounting profession were Modugu and Anyaduba [18]; Fasua and Osifo [9] who wrote about progressive growth of fraud incidence in Nigeria both in private and public sectors via financial reports window dressing, manipulation, and earning management and this frauds have negative effects on corporate earnings and reasonable assurance offers to different stakeholders.

Conversely, some of these studies are theoretical while many of them which are empirical studies rely so much on primary data for their analysis. For instance, Enofe, Agbakpolor and Oyarebu-ibrahim [7] examine forensic accounting and corporate fraud in Nigeria collected data from primary source data. Modugu and Anyaduba [18] investigate forensic accounting and financial fraud in Nigeria and gathered their data from primary source. Ekwueme and Jugu [6] wrote on employers' perception on necessary skills of forensic accountants also make use of primary data. Ramadhan [21] studies certified accountants' perception of forensic accounting education employed primary data. However, this study is motivated to investigate the role of forensic audit on management frauds in Nigerian deposit money banks with the aim to source for data from secondary source at which some were collected from the study of Ezeagba [8] as well as accounts of some listed deposit money banks in Nigeria. This approach was used because the annual reports are audited is mostly consistent, reliable, regular medium to generate dependable information and disseminate in a systematic manner with stakeholders if not smoothing.

\subsection{Research Questions}

The following fundamental research questions were raised to ascertain the efficacy of the roles of forensic audit on management frauds in Nigerian deposit money banks and stated thus:

1) can forensic accounting/audit mechanisms be effective in curbing management frauds in deposit money banks in Nigeria?

2) is there any meaningful nexus between forensic accounting and faithful representation of financial statements?

3 ) is there any meaningful nexus between forensic accounting and qualitative characteristics of financial records?

\subsection{Objectives of the Study}

The objective of this study is to:

1) investigate the role of forensic audit on management frauds in Nigerian deposit money banks.

2) to investigate the nexus between forensic audit and faithful representation of financial statements;

3 ) to examine if any meaningful nexus exists between forensic accounting and qualitative characteristics of financial records.

\subsection{Statement of Hypotheses}

The hypothesis formulated for this study was tested in null form so as to be in the same direction with the above stated objectives. For the purpose of this research, the hypothesis formulated states that:

1) forensic audit does not meaningfully assist accounting mechanism in curbing management frauds in deposit money banks in Nigeria;

2) forensic audit does not have any meaningful nexus with faithful representation of financial statements;

3) forensic audit does not have any meaningful nexus with qualitative characteristics of financial records.

\section{Review of Relevant Literature}

Conceptual review.

\subsection{Forensic Accounting}

Forensic Accounting is the study that gives most of attention to and knows a lot in the practice area of accounting profession that involves engagements of skilled professionals in the field of account to investigate the unfair position of financial statement with views of unravelling mismanagement of funds or abuse of office or misuse of official status while in office or position of authority which in most situations may endanger the financial position of an organisation and resulted to actual or anticipated disputes or litigation. Onodi, Okafor, and Onyali [20] are of an opinion that "Forensic" means "suitable for use in a court of law". In the same vein, forensic experts are also forensic auditors or investigative auditors who have to render expert evidence or fact at the pre- trial as well as trial.

Skousen and Wright [23] view forensic accounting as a special profession with the methods and tools to examine practices which seek for assurance, attestation together with consultative perspective to offer legal facts. Moreover, forensic accounting is a peculiar field that abridges, presents as well as interprets fragile financial matters cystally and accurately in a court of law as a professional witness. Forensic accountant should possess the following personal attributes such as organizational skills, curiosity, persistence, creativity, self-confidence, and sound professional judgment as noted by Singleton and Singleton 
[22].

Finally, Houston Community College [13] sees forensic accounting in three perspectives, namely: time, purpose and peremptory. "Time: Forensic accounting focuses on the past, although it may do so in order to look forward". "Purpose: Forensic accounting is purpose for a particular forum or in anticipation of presentation before a legal forum". "Peremptory: Forensic accountants may be employed in a wide variety of risk management engagements within business enterprise as a matter of right, without the necessity of allegations".

\subsection{Management Fraud}

Management fraud can be called earnings management, income smoothing or financial statements frauds occupational fraud for organization (Zimbelman and Albrecht [25]. It is also defines as "an attempt on the part of the firm's management to reduce abnormal variations in earnings to the extent allowed under sound accounting and management principles' Beidleman [2]. Management fraud is a legitimate right of the person who is on official position of management to refine financial records.

Those who are charged with fiduciary duty either uses their discretion to modify earnings by diverse accounting choices or they alter procedures for the sake of earnings targets. For instance, management may alter profit from one financial period to the other or cut back advertising cost. The latter case is called real income smoothing, while the former represents accrual-based management fraud or income smoothing Dreyer [5].

Therefore, Goran and Bojana [10] argue that the distinction between them is that accrual-based management fraud; income smoothing does not manipulate operations and does not permeate company value via operations while real income smoothing does Gunny [12]. Accruals arise when there is a discrepancy between the timing of cash flows and the timing of the accounting recognition of the transaction". Accruals are such items on the balance sheet that represent liabilities (Accounts Payable) or non-cash-based assets (e.g. Account Receivables) that are recorded on the balance sheet without actual payments being received or made. Accruals can be divided into discretionary and nondiscretionary accruals.

\subsection{Financial Reporting Quality}

The need for building a simple to understand instrument to examine the qualitative characteristics of financial reporting considering all proportions of decision usefulness is expressly stipulated in International Accounting Standard Board. Therefore, this method includes all the qualitative features due to the fact that these characteristics determine the importance of financial reporting data (International Accounting Standard Board) [14]. These can be generally categorised into two namely: relevance and faithful representation; and the enhancing qualitative characteristics which include reliability, understandability, comparability, verifiability and timeliness. Fundamental qualitative features decide the content of financial reporting information. These include relevance and faithful representation. Relevance means the ability of making clarity in the decisions made by users in their capacity as capital providers Idekwulim [15].

\subsection{Theoretical Review}

The theoretical review for underpinning this study focuses on positive accounting theory and framework of the fraud exposure rectangle. The theory gives primacy to a particular view on how management behaves and engages in frauds while last theory shows what forensic experts examine in order to unravel management frauds and financial statement frauds.

\subsubsection{Positive Accounting Theory}

Positive accounting theory is the theory that reveals how management and financial manager respond and the impacts of their responses, Belkaou [3]. In actual fact, the main quest of positive accounting mechanism is to expand and predict management selected choice. This is carried out by evaluating the cost and gains of financial statements disclosure in connection with different individuals together with allotment of relative scare resources within the economy. Watts \& Zimmerman [24].

The theory is founded on the plan that managers, shareholders, and other stakeholders are not irrational. They make efforts to maximize their utility which is directly associated with their return on investment and resources. Positive accounting theory expatiates factors that permeates the accounting and managerial world and test the validity empirically. Graffikin [11]

\subsubsection{Financial Statement Fraud - Exposure Rectangle}

Financial statement fraud - exposure rectangle consists of: management and the board of directors, company's relationships with other entities, the organization and its industry, and financial results and operating characteristics. Under this framework, forensic experts can only be successful in detecting and preventing management frauds when the followings are investigated (Albrecht, Albrecht \& Albrecht [1].

The management and the board of director's backgrounds must be investigated. These include: kinds of organization, activities, director, auditors' independence, financial records quality. Besides, management's motivations should be examined together with her scope of influence in policy taking as well as in making decision for the companies. The theory holds that it is paramount to understand these if forensic experts must accomplish his goal Dreyer [5].

Company's relationships with other entities: The theory believes that management frauds and financial statement frauds often occur with the assistance of other stakeholders. These include the association between the company and financial institutions, lawyers, related companies and individuals, investors, auditors, and regulatory bodies. Albrecht, Albrecht \& Albrecht [1]. 
The organization and its industry: In this theory hypothesis, some questions need to be asked in order to comprehend exposure to management fraud because it holds that management frauds normally perpetrated by forming a company that makes it less difficulty to conceal fraud.

Financial results and operating characteristics: The theory calls for analytical comparison of the company in question with similar companies in the same industry. The instruments for this exercise include: horizontal, vertical and ratio analysis, adequacy of disclosures and objective analyses coupled with risk factors though based on the first three factors.

In order to accomplish the mission, Kristic [17] opine that the forensic professional should have resonance knowledge of accounting "as well as auditing, good communicationverbal, written and investigative skills, independence and a substantial degree of understanding about usage of information technology in accounting and auditing procedures".

\section{Methodology}

The study made use of quantitative method in the analysis. The step taken in the examination are presented below.

\subsection{Specification of the Model}

A model was form to suit this study so as to achieve the stated objective with adequate variables in order to improve the fit, thereby estimating the most likely relationship among the variables. Furthermore, the dependent variable is forensic accounting mechanism index (FAMI) while the independent variables comprises of faithful representation of financial records (FRFR); understandability of financial records (UFR) and corporate governance index (CGI). This was stated below as:

$$
\mathrm{FAMI}=f(\mathrm{FRFR}, \mathrm{UFR}, \mathrm{CGI}, \mathrm{Ut})
$$

Expressing equation (1) more explicitly, we have:

$$
\mathrm{FAMI}=\beta_{0}+\beta_{1} \mathrm{FRFR}_{\mathrm{it}}+\beta_{2} \mathrm{UFR}_{\mathrm{it}}+\beta_{3} \mathrm{CGI}_{\mathrm{it}}+\mathrm{Ut}
$$

Where:

FAMI $=$ forensic accounting mechanism index; $\mathrm{FRFR}=$ faithful representation of financial records; $\mathrm{UFR}=$ understandability of financial records; $\mathrm{CGI}=$ corporate governance index; $\beta_{0}=$ Constant intercept; $\beta_{1}-\beta_{3}=$ Parameters or coefficients to be estimated; $f=$ Functional notation and $\mathrm{U}_{\mathrm{t}}=$ Stochastic error term.

\subsection{Estimation Technique, Variables, Samples and Data Source}

The study adopts econometric approach to investigate the role of forensic audit on management frauds in Nigerian deposit money banks using different techniques such as descriptive analysis and the use of panel regression technique method of analysis. The study made use of annual data obtained from the secondary source which were gathered from the audited financial statements accounts of the specified listed Deposit Money Banks in Nigeria.

The data were based on 2019 presentation reports of the deposit money banks from the National Bureau of Statistics [19]. This reporting period was chosen due to the fact that it was the period when banks were informed to compulsorily adopt IFRS as basis for issuing annual reports and upon which the financial reporting qualities of the study period for this investigation were domiciled.

\section{A Priori Expectation}

A priori expectation is anchor on the principles of economic theory and refers to the expected relationship between the dependent variable and the independent variable (s). It is expected that the role of forensic audit curbing management frauds will affects the deposit money banks positively.

$$
\beta_{0} \neq 0 ; \beta_{1} \geq 0 ; \beta_{2} \geq 0 ; \beta_{3} \geq 0
$$

\section{Presentation of Results and Discussion}

The results of the findings from the study are presented sequentially and discussed as follows:

\subsection{Descriptive Analysis}

The descriptive analysis made use of time series data spanning from January, 2019 through to December, 2019. It was used because it presents the result in a more meaningful way for simpler interpretation of data result and simpler summary of results; it helps to determine the normalcy of the distribution.

Table 1. Result of Descriptive Statistics.

\begin{tabular}{lllll}
\hline & FAMI & FRFR & UFR & CGI \\
\hline Mean & 0.607042 & 658.6081 & 7.246334 & 0.247054 \\
Median & 0.600000 & 5.295735 & 7.019817 & 0.019603 \\
Maximum & 1.000000 & 12090.26 & 9.279750 & 10.03326 \\
Minimum & 0.300000 & -10235.60 & 4.860386 & -2.422443 \\
Std. Dev & 0.165895 & 2700.157 & 1.450070 & 1.267768 \\
Skewness & 1.400021 & 1.212964 & 0.013730 & 6.546755 \\
Kurtosis & 4.067403 & 11.68711 & 1.367243 & 51.82467 \\
Jarque-Bera & 26.56461 & 240.6633 & 7.8888837 & 7559.395 \\
Probability & 0.000002 & 0.000000 & 0.019362 & 0.000000 \\
Observations & 12 & 12 & 12 & 12 \\
\hline
\end{tabular}

Author's computation, 2020

The table 1 showed the descriptive analysis results of all the variables involved in examining the role of forensic audit on management frauds in Nigerian deposit money banks for the period of January 2109 to December 2019. The result revealed that on average, FAMI, FRFR, UFR and CGI varies from $0.61,658.8,7.25$ and 0.25 respectively to minimum of $0.30,-102,4.86$ and -2.42 . The maximum of the variables were recorded as 1.00, 12090, 9.28 and 10.0. Also the standard deviation values $0.166,2700.1,1.45$ and 1.267 indicated that the variables in the study were been deviated from their respective average or expected value. More so, it was discovered that all the variables were positively skewed 
with the skewness coefficient of $1.40,1.21,0.01$ and 6.55 respectively thus implied that the distribution of FAMI, FRFR, UFR and CGI under the study had a long tail to the right. Kurtosis measures the peakedness or flatness of the distribution of the series. If the kurtosis is above three, the distribution is peaked or leptokurtic relative to the normal and if the kurtosis is less than three, the distribution is flat or platykurtic relative to normal. From the Table 1, FAMI, FRFR, UFR and CGI with coefficient of 1.64, 1.67, 2.78, 2.47 and 1.59 which were less than three which implies flat or platykurtic that is flatter than a normal distribution with wide peak. The Jarque - Bera and probability values revealed that the all the variables that is FAMI, FRFR, UFR and CGI were statistically significance with an associate probability of 0.000 thus, reveal that the variables are normally distributed when measure at critical level. This means that the possibility of outlier does not exist in the distribution in examining the role of forensic audit on management frauds in Nigerian deposit money banks for the period of January 2109 to December 2019.

\subsection{Fitted Regression Model}

It should be recalled that there are research questions, objective and hypothesis in the study. Hence, this was tested accordingly. In order to test Hypothesis which stated that forensic audit does not assist accounting mechanism is in curbing management frauds in deposit money banks in Nigeria fitted regression estimate was employed on the variables of interest namely; FAMI, FRFR, UFR and CGI.

Table 2. Result of Regression Analysis.

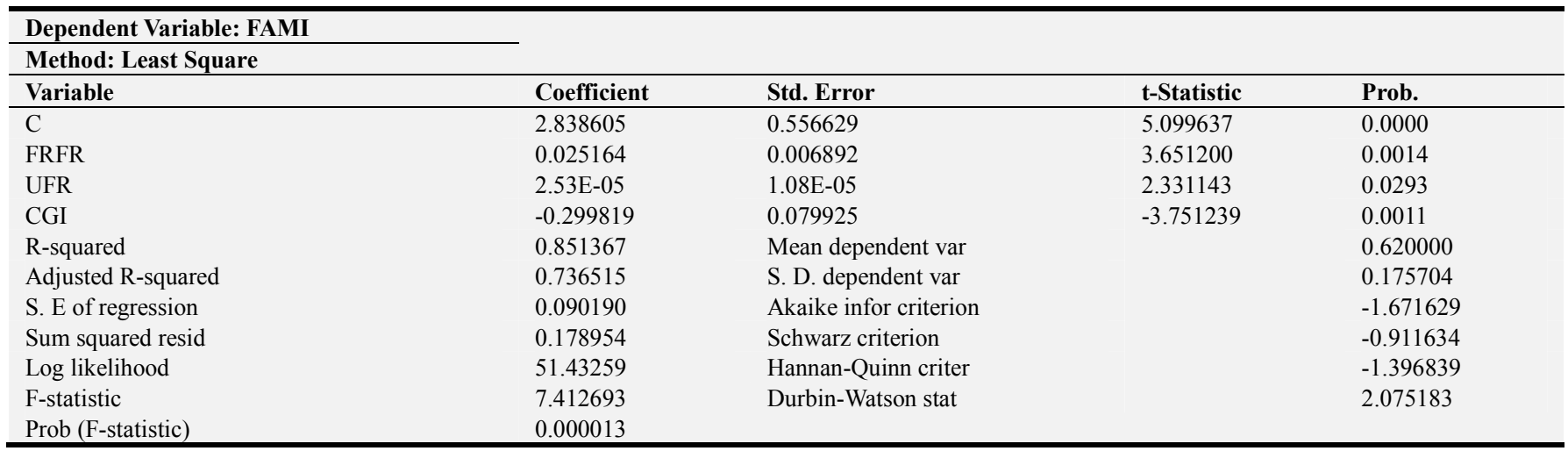

Author's computation, 2020

From the fitted regression result above, the forensic audit/ accounting mechanism is effective in curbing management frauds in Nigeria deposit money banks. From the result, it was revealed that a positive linear nexus exists between faithful representation of financial records (FRFR) and understandability of financial records (UFR) in Nigeria. The result specifically revealed that an improvement in faithful representation of financial records (FRFR) and understandability of financial records (UFR) will lead to $2.51 \%$ and $2.53 \%$ improvement respectively on forensic accounting mechanism (FAM) during the period under investigation in Nigeria. Conversely, the result revealed the negative relationship with corporate governance (CGI) on forensic accounting mechanism (FAM). The thus implies that an effort to further deter adequate corporate governance will negatively decrease the role of forensic auditors performance by $30 \%$ respectively. This implies that a unit change in the ineffectiveness in corporate governance index of an organization will facilitate $30 \%$ reduction in the level of forensic accounting mechanisms.

The test for the significance of the estimated parameters of the fitted regression model using the probability value showed that the probability value of faithful representation of financial records (FRFR), understandability of financial records (UFR), corporate governance (CGI) were $0.001<$ $0.05,0.029<0.05$ and $0.001<0.05$ respectively. The probability value of showed the statistical significance of the role of forensic audit on management fraud of deposit money banks' in Nigeria. The standard error test for the parameters also established the same result and thus implies the statistical significance of the estimated parameters for (FRFR) faithful representation of financial records and (UFR) understandability of financial records and corporate governance were statistically insignificance in examining the roles of forensic audit on management of fraud in deposit money banks' in Nigeria. Moreover, it was discovered from the study that the Adjusted R-square value of 0.736515 revealed that 73.6 percent improvement in forensic accounting mechanism (FAM) can be explained by the power of the independent variables (FRFR, UFR and CGI) in Nigeria. The F-statistic value of 741.2693 with the probability value of $0.000<0.05$ showed that the fitted regression model was statistically significance and thus appropriate, reliable and acceptable for assessing the role of forensic audit on management fraud in Nigeria deposit money banks.

The test for the economic or theoretical significance of the parameters determined based on the sign of the estimated parameters which revealed that faithful representation of financial records (FRFR) and understandability of financial records (UFR in Nigeria were positively signed. Thus, it implies that faithful representation of financial records 
(FRFR) and understandability of financial records (UFR) positively affected the role of forensic audit on management fraud in Nigeria deposit money banks' during the period under examination. Thus, the result affirmed that faithful representation of financial records (FRFR) and understandability of financial records (UFR) are the most influencing variables that are capable of promoting forensic audit on management fraud in Nigeria deposit money banks.
More so, the Durbin Watson test statistics of 2.07 explored that the model is free from any serial autocorrelation. However, the result of the model followed their respective $a$ priori expectation with the exception of corporate governance index which proved negative instead of positive. Therefore, the null hypothesis should be rejected and the alternative hypothesis accepted accordingly.

Table 3. Heteroskedasticity Test.

\begin{tabular}{llll}
\hline \multicolumn{1}{l}{ Heteroskedasticity Test: } & & & \\
\cline { 1 - 2 } Breusch-Pagan-Godfrey & & & \\
\cline { 1 - 3 } F-statistic & 0.237573 & Prob. F (3, 67) & 0.8699 \\
Obs*R-squared & 0.747319 & Prob. Chi-Square (3) & 0.8620 \\
Scaled explained SS & 1.020746 & Prob. Chi-Square (3) & 0.7962 \\
\hline
\end{tabular}

Source: Author's Computation, 2020

Table 3 shows the F-statistic and Obs*R-squared values of 0.237573 as well as 0.747319 with p-values of 0.8699 together with 0.8620 respectively reveal the absence of heteroskedasticity in the model since the F-statistic and Obs*R-squared values and $\mathrm{P}$-values of 0.8699 and 0.8620 are higher than the critical values at 5\% level of importance. Therefore, the researcher can now reach the conclusion that there is never presence of Heteroskedasticity in the model.

\section{Conclusion and Recommendations}

This study examines the roles of forensic audit on management fraud in Nigeria deposit money banks' hence; this is a meaningful addition to existing literature especially in Nigeria. In examining the roles of forensic audit on management fraud in Nigeria deposit money banks, the study employed descriptive statistics and panel fitted regression test. However, the study addressed three research objectives and tested three research hypotheses with econometric tests.

The analysis from the hypothesis one result showed that there is meaningful and positive nexus between forensic accounting on prevention of management frauds. The second hypothesis showed that there is a strong positive nexus between forensic accounting mechanism and faithful representation. The analyses on the third hypothesis establish a very strong connection between forensic accounting mechanism and understandability of financial statements. The overall summary of the F - statistics of the model establish the fitness and the statistical significance. Given by the rarity of this study on the fundamental school of thought in Nigeria, this study tends to provide additional literature on the subject of the roles of forensic audit on management fraud in Nigeria deposit money banks. Based on the results revelation from the study, the followings recommendations are put forward:

That accountants should undergo periodic training on forensics to refresh their knowledge on the investigative aspect and be in a position to offer sound advice that could reveal those issues which might have work against quality assurance of financial statements.

Forensic auditors should be engaged to buttress the internal control mechanism of various organizations while financial reports are used as standard towards enhancing qualitative attributes in order to appreciate organizations that have comply to the requirements.

Accounting Regulators in Nigeria such as the Financial Reporting Council and other relevant accounting bodies should develop programme to ensure certification of accountants in the area of in-house training, workshops and seminars for accountants.

Government of Nigeria through the National Assembly should promulgate laws to make forensic audits a compulsory requirement for public quoted companies.

\section{References}

[1] Albrecht, W. S., Albrecht, C., \& Albrecht, C. C. (2008). Current trends in fraud and its detection: Information Security Journal: a Global Perspective, 17. www.ebscohost.com.

[2] Beidleman, C. R. (1973). Income Smoothing: The Role of Management. The Accounting Review, 653-667.

[3] Belkaoui, A. R. (2014). Accounting theory. $5^{\text {th }}$ edition: USA, Learning Solution Specialty Publications Ltd. Central Bank of Nigeria. (2019). Central Bank of Nigeria Financial Stability Report.

[4] Centre for Forensic Studies (2010). Roundtable on the role of forensic and investigative accounting: challenges for the banking Industry. Nigerian Institute of Advanced Legal Studies, Lagos, Nigeria.

[5] Dreyer, K. (2014). A history of forensic accounting. Grand Valley State University.

[6] Ekwueme, C. M., \& Jugu, Y. G. (2013). Employers' perception on necessary skills of forensic Accountants.

[7] Enofe, A. O., Agbakpolor, C. A., \& Oyarebu-Ibrahim, P. Y. (2015). Forensic accounting and corporate fraud in Nigeria. IIARD Journal of Accounting and Finance Management, 1 (6).

[8] Ezeagba, C. E. (2014). The role of forensic accounting and quality assurance in financial reporting in selected commercial banks in Nigeria. International Journal of Economic Development Research and Investment, 5 (2). 
[9] Fasua, H. K., \& Osifo, I. U. O. (2016). Financial control and fraud prevention in the public sector. International Journal of Advanced Academic Research, 2 (8).

[10] Göran, A., \& Bojana C. (2012). The impact of income smoothing on firm value after the Sarbanes-Oxley Act: An empirical research on us public companies from 2006-2012.

[11] Graffikin, M. J. R. (2007). Accounting research and theory: The age of neo-empiricism. Australasian Accounting and Business and Finance Journal, 1 (1), 1-19.

[12] Gunny, K. A. (2010). The relation between earnings management using real activities manipulation and future performance: Evidence from meeting earnings benchmarks. Contemporary Accounting Research, 855-888.

[13] Houston Community College. (2011). Forensic and investigative accounting. Chicago: www.CCHGroup.com.

[14] IASB (2008). Exposure Draft on an improved conceptual framework for financial reporting: The objective of financial reporting and qualitative characteristics of decision-useful financial reporting information.

[15] Idekwulim, P. C. (2014). Teach yourself IFRS, Lagos, Nigeria: Picca global concept.

[16] Institute of Chartered Accountants in England and Wales. (2009). Forensic accountant and expert witness accreditation: A benchmark for the profession. www.icaew.com.

[17] Krstic, J. (2009). The role of forensic accountants in detecting frauds in financial statements. Facta Universities, Economic and Organization, 6 (3), 295-302.
[18] Modugu, K. P., \& Anyaduba, J. O. (2013). Forensic accounting and financial fraud in Nigeria: an empirical approach. International Journal of Business and Social Science, 4 (7), 281-282.

[19] National Bureau of Statistics (2019) Download Statistics on Banks Financial Statements.

[20] Onodi, B. T., Okafor, T. G., \& Onyali, C. I. (2015). The impact of forensic investigative methods on corporate fraud deterrence in banks in Nigeria. European Journal of Accounting Auditing and Finance Research, 3 (4), 69-85.

[21] Ramadhan, S. (2015). Certified accountants' perception of forensic accounting education. International Journal of Finance and Accounting, 4 (2).

[22] Singleton, T. W., \& Singleton, A. J. (2007). Why don't we detect more fraud? Journal of Corporate Accounting and Finance, 18 (4): 7-10.

[23] Skousen, C., \& Wright, C. (2008). Contemporaneous risk factors and the prediction of financial statement fraud. Journal of Forensic Accounting 6, 37-62.

[24] Watts, R. L., \& Zimmerman, J. L. (1986). Positive accounting theory. London: Prentice-Hall.

[25] Zimbelman, M. F., \& Albrecht, C. C. (2012). Forensic accounting, $4^{\text {th }}$ edition, International edition, Canada: Nelson Education Ltd. 